\title{
SASTRA SEBAGAI MEDIA KOMUNIKASI LINTAS BUDAYA: Tinjauan Bumi Manusia Karya Pramoedya Ananta Toer
}

\author{
I Nyoman Suaka \\ Prodi Pendidikan Bahasa dan Sastra Indonesia \\ IKIP Saraswati \\ Email, imansuaka@yahoo.co.id
}

\begin{abstract}
Abstrak
Pengarang Indonesia yang paling banyak mendapat sorotan dunia adalah Pramoedya Ananta Toer, seorang pengarang kontroversial pada era orde baru. Sastrawan besar Indonesia ini menghasilkan 53 buku yang telah diterjemahkan ke dalam 40 bahasa di dunia. Berdasarkan angka-angka itu, dapat dikatakan bahwa karya-karya Pramudya mampu menerobos sastra dunia. Beberapa kali Pramudya masuk nominasi untuk meraih hadiah nobel di bidang kesusastraan. Novelis hebat ini namanya menjulang tinggi dengan karya-karyanya, seperti Keluarga Gerilya, Cerita dari Blora, Bukan Pasar Malam, Bumi Manusia, Anak Semua Bangsa, Jejak Langkah, Rumah Kaca, dan Gadis Pantai. Novel Bumi Manusia (2001) yang dikerjakan selama mendekam di Pulau Buru sebagai tahanan politik merupakan karya puncak kepengarangan Pramudya. Isi dan penyajiannya sangat menarik dan menantang, sekaligus mampu menghadirkan beberapa pesoalan lintas budaya. Tokoh Sanikem alias Nyai Ontosoroh tidak silau dengan pengaruh budaya Barat, untuk berubah sebagai wanita modern. Padahal, jalan ke arah itu dengan mudah didapat karena sebagai selir Tuan Mellema yang kaya dan mempunyai kekuasaan. Tokoh Nyai ciptaan Pramoedya ini walaupun mendapat gempuran budaya Eropah, tetap pada pendirian dengan konsep kejawaan. Sedikit pun tidak mengalami guncangan budaya (cultural shock) seperti halnya tokoh-tokoh lain dalam sastra Indonesia.
\end{abstract}

Kata kunci : sastra Indonesia, bumi manusia, lintas budaya

\section{Pendahuluan}

Sastra Indonesia merupakan karya sastra modern sebagai hasil pengaruh kebudayaan dan kesusastraan Barat yang ditulis dalam bahasa Indonesia, yang mulai muncul pada dasa- warsa kedua pada abad kedua puluh (Rosidi, 1991:755). Adaptasi budaya asing dalam menghadapi budaya global, terutama budaya Barat, sebenarnya sudah ada pada awal perkembangan sastra Indonesia Modern. Hal ini diakui oleh Darma (1998:3) bahwa budaya asing yang paling kuat berpengaruh terhadap kehidupan sastra Indonesia adalah budaya Barat. Pengaruh budaya Barat terhadap sastra Indonesia tidak hanya terjadi pada karya sastra itu sendiri, tetapi juga terjadi pada pemikiran yang ada di balik karya sastra. Pengaruh budaya Barat dalam karya sastra terletak pada konvensi penulisan karya sastra misalnya genre, tema, penyampaian gagasan, dan gaya bercerita.

Pandangan pengaruh Barat dalam dunia kesuastraan Indonesia modern, menurut Santosa (2011:394), menyebabkan segala teori sastra diimpor dari Barat mulai strukturalisme, semiotika, komparatif, pragmatik, mimesis, ekspresif, resepsi sastra, hermeneutik, sampai pada dekonstruksi masuk ke negeri kita dan mendapat sambutan meriah. Dengan demikian, sastra sebagai media komunikasi lintas budaya tidak saja bergerak pada tataran teoretis, tetapi juga tampak menonjol pada tema-tema karya sastra. Membicarakan karya sastra tidak dapat dilepaskan dari pengarangnya karena keduanya memiliki hubungan yang amat kompleks. Latar budaya politik pengarang sangat kuat berpengaruh terhadap karya yang dihasilkan.

Berdasarkan uraian di atas, muncul pertanyaan bagaimanakah potret sastra Indonesia sebagai media komunikasi lintas budaya? Pertanyaan tersebut dibahas dengan mengambil karya pengarang Pramoedya Ananta Toer dalam novel Bumi Manusia (2001) sebagai objek analisis. Pramoedya (selanjutnya disebut Pram) dipilih karena sampai saat ini dia paling banyak mendapat sorotan dunia melalui beberapa penghargaan internasional dan beberapa kali masuk nominasi peraih nobel bidang sastra. Novel Bumi Manusia kini semakin populer karena difilmkan tahun 2019 sebagai bagian dari budaya pop. Sutradara Bumi Manusia, Hanung Bramantyo, skenario Salman Arsito, poduksi Falcon Pictures. Menurut Choudori (2019), film 
Bumi Manusia ini menjadi penanda bahwa Indonesia masih bertahan untuk menjadi negara yang bebas berekspresi karena film ini tampil tanpa gangguan. Dalam analisis ini tidak dibahas filmisasi Bumi Manusia, tetapi dibicarakan kreativitas Pramudya lewat tokoh protagonis Nyai Ontosoroh.

Banyak peneliti yang telah membahas Pram dengan karyanya yang monumental pascaorde baru seperti Djokosujatno (2004), Bandel (2013), Wahyudi (2008), Haryoto (2007), dan Sudibyo (2004). Dari beberapa peneliti tersebut, Djokosujatno dan Wahyudi mengulas Bumi Manusia yang kemudian dijadikan bahan melengkapi kajian ini. Wahyudi melihat dari teori sastra postkolonial. Bandel meninjau novel Gadis Pantai dan novel Jamangilak Tak Pernah Mengangis dari perspektif perempuan pesisir. Kedua novel ini diperbandingkan sebagai sebuah studi sastra komparatif. Haryoto mengkaji Gadis Pantai dari perspektif religius. Temuannya cukup mengejutkan karena novel tersebut dinilainya sebagai sebuah impotensi agama. Berbeda dengan Sudibyo yang menganalisis novel kumpulan cerpen Cerita dari Blora dari aspek historis. Penulis sendiri mengkaji dari aspek kultural terutama lintas budaya.

Damono (1978:1) menegaskan "sastra tidak begitu saja jatuh dari langit." Pernyataan tersebut mengandung maksud bahwa sastra diolah melalui proses yang panjang seorang pengarang. Sebagai hasil permenungan pengarang, yang pada hakikatnya merupakan tanggapan atau respons pengarang terhadap situasi dan kondisi sosial budaya di sekelilingnya. Selanjutnya, karya sastra diciptakan untuk dinikmati, dipahami, dan dimanfaatkan oleh masyarakat. Sastrawan itu sendiri adalah anggota masyarakat. Ia terikat oleh tatanan sosial tertentu. Dengan demikian, sastrawan, karya sastra, dan masyarakat memiliki hubungan yang sangat erat dan saling terkait sehingga memiliki hubungan timbal balik antara ketiga unsur tersebut.

\section{Pembahasan}

Pram memunculkan seorang tokoh perempuan yang unik, Nyai Ontosoroh alias Sanikem dalam Bumi Manusia. Lewat tokoh Ontosoroh, Pram menganggap sosok Nyai yang saat itu dianggap pribumi yang bodoh dan malas, menjadi Nyai yang terpelajar, mandiri, dan pekerja keras. Ini dibuktikan lewat kesuksesannya dalam mengelola pertanian dan perusahaan almarhum milik suaminya. Sekalipun Nyai Ontosoroh menguasai perusahaan dan pertanian milik warisan almarhum suaminya, ia tidak mengubah status dirinya dari seorang "Nyai" menjadi "Nyonya Besar". Ia malahan memantapkan dirinya sebagai seorang "Nyai". Istilah nyai pada era kolonial merupakan julukan sebagai istri tidak sah (simpanan) orang Belanda.

Djokosudjatno dalam Horison No. XXXV/9/2000 menggolongkan novel Bumi Manusia, Anak Semua Bangsa, Jejak langkah, dan Rumah Kaca sebagai novel tetralogi karya Pramudya. Karya-karyanya ini sebagai karya puncak pengarangnya, sangat menarik karena isi dan penyajiannya, sekaligus kuat dalam menghadirkan beberapa genre sebagai novel realis, novel sosial, novel politik, novel psikologis, dan novel biasa. Dalam hal tema, lebih banyak lagi yang diungkapkannya, mulai dari mentalitas, kebangkitan suatu bangsa, kemanusiaan, pendidikan, perjalanan, sampai tema-tema kecil, seperti perpisahan, dendam, berbagai jenis transportasi, dan banyak lagi yang lain. Aspek lain yang menarik dari katralogi Pram tersebut, yaitu isinya yang kosmopolit dan ensiklopedis. Hal-hal ini merupakan ciri-ciri yang terdapat dalam roman besar Perancis, pascarevolusi 1789 dan awal abad XX.

Novel Bumi Manusia menampilkan bermacam-macam tokoh dari berbagai penjuru dunia dengan latar belakang yang berbeda. Masalah tiap-tiap tokoh dipertautkan sehingga mendukung makna judul novel tersebut, Bumi Manusia. Pram menampilkan tokoh dari berbagai negara, yakni orang Belanda, Perancis, Afrika, Inggris, Cina, Jawa, Sunda, dan Sumatra. Bumi Manusia benar-benar membumi. Kehadiran mereka sudah merupakan suatu kenyataan global. Tokoh-tokoh ini dilukiskan dalam latar belakang tiga kota pelabuhan, yakni Surabaya, Semarang, dan Batavia yang merupakan tempat persinggahan berbagai bangsa. Latar belakang cerita yang lain meluas sampai ke Afrika Selatan, Belanda, Jepang, Cina, Amerika, Philipina, dan banyak negara lain.

Penampilan tokoh-tokoh yang membumi dan seting cerita serta penerimaan masyarakat dunia terhadap sastrawan Pramudya telah membuktikan bahwa posisi tawar sastra Indonesia cukup kuat sebagai media komunikasi lintas budaya. Rosidi dalam Horison nomor XLI/2006 
menyebutkan bahwa Pramudya adalah sastrawan terbesar dalam bahasa Indonesia. Dialah satusatunya sastrawan Indonesia yang berkali-kali dicalonkan untuk mendapat hadiah nobel untuk bidang kesusastraan. Karya-karya Pramudya tak kalah hebat dari beberapa orang sastrawan yang sudah mendapat hadiah tersebut. Panitia nobel, menurut Rosidi, tidak selalu hanya menilai dari mutu karya seseorang, tetapi juga memperhatikan latar belakang budayanya. Setiap pengarang dengan latar belakang budaya besar pada waktunya secara bergiliran mendapatkan hadiah nobel.

Pada massa orde baru, buku-buku Pramudya yang ditulis dan diterbitkan sebelum pengarangnya ditahan, dilarang beredar di Indonesia, tetapi dicetak ulang di Malaysia. Bahkan, novel Keluarga Gerilya dijadikan buku bacaan wajib para pelajar Malaysia selama bertahun-tahun. Penerjemahan ke dalam bahasa Inggris dan bahasa-bahasa asing lainnya pun kian banyak dilakukan. Karya-karya Pramudya ketika mendekam di Pulau Buru terbit dengan bebas di Malaysia, sedangkan pemerintah RI segera melarangnya. Karya kreatifnya itu telah mengantarkan sastra Indonesia sebagai media komunikasi lintas budaya tingkat dunia.

\section{Lintas Budaya}

Lintas budaya yang dimaksudkan di sini bukan semata-mata karena letak geografis, melainkan juga karena permasalahan prinsip yang dimunculkan Pram dalam Bumi Manusia, seperti budaya feodal, kolonial, pascakolonial (modern), pribumi dan nonpribumi, dan transformasi budaya. Lintas budaya ini dialami oleh tokoh Nyai Ontosoroh. Nama asli Nyai Ontosoroh adalah Sanikem, kakaknya bernama Paiman. Ayahnya bernama Sastrotomo seorang juru tulis pabrik gula di Tulangan. Dari penamaan tersebut, tampaknya ada keganjilan karena seorang ayah yang berpendidikan kelas menengah ketika itu memberikan nama pada anaknya Sanikem dan Paiman yang identik dengan status golongan bawah. Citra status itu ditunjukkan bahwa "jangankan untuk menggosok gigi, mandi dengan baluran sabun, dan hendak pergi kemanapun Nyai Ontosoroh tidak pernah menggunakan alas kaki."

Perubahan gaya hidup Ontosoroh baru dirasakan setelah menjadi Nyai dari Tuan
Mellema. Tuan Mellema ini kemudian mengajarkan cara menggosok gigi, diajarkan bahasa Melayu, Belanda, dan keterampilan di bidang pertanian dan pemeliharaan hewan. Hal tersebut tampak dalam kutipan berikut.

"Dia yang mengajar aku segala pertanian, perusahaan, pemeliharaan hewan, pekerjaan kantor. Mula-mula diajari aku bahasa Melayu, kemudian membaca dan menulis, setelah itu juga bahasa Belanda. Papamu bukan hanya mengajar dengan sabar, juga menguji semua yang diajarkannya. Ia haruskan aku berbahasa Belanda dengannya, kemudian diajarinya aku berurusan dengan bank, ahli-ahli hukum, aturan dagang, semua yang sekarang mulai kuajarkan juga padamu" (2001:68).

Nyai Ontosoroh benar-benar menjadi murid yang baik, cerdas, waspada, dan rajin. Di kemudian hari justru lebih pandai daripada gurunya, Tuan Mellena. Sosok Nyai dari kehidupan kelas bawah berubah menjadi kelas menengah, diakui oleh Minke, tokoh sentral Bumi Manusia. Minke yang mennjadi menantu Tuan Mellema memanggil Nyai Ontosoroh dengan sebutan Mama, seperti kutipan berikut.

'........Tak dapat aku katakan dia bodoh. Bahasa Belandanya cukup fasih, baik, dan beradab; sikapnya pada anaknya halus dan bijaksana, dan terbuka tidak seperti ibu-ibu pertiwi; tingkah lakunya tidak jauh berbeda dengan wanita Eropah terpelajar, Ia seperti seorang guru dari aliran baru yang bijaksana itu......".(2001: 20)

Berdasarkan dua kutipan di atas, diketahui bahwa sosok Nyai dapat beradaptasi dengan budaya baru, bahkan ia dapat disebut manusia modern. Berbeda halnya dengan kesan selama ini bahwa sebutan "nyai" adalah istri tidak sah (simpanan) dari pejabat-pejabat Belanda ketika itu hanya sebagai pemuas nafsu. Tidak berlebihan, Apsanti (2004:73) menyebutkan Ontosoroh sebagai figur kontradiktif, manusa, tetapi juga seorang dewi, ratu, tetapi juga pekerja keras, anggun, tetapi suatu waktu bisa pula menjadi vulgar, sederhana, tetapi sekaligus kompleksitas, berkuasa dan keras. Namun, di sisi lain sering 
kali ia memperlihatkan pengertian dan kelembutan.

Melalui tokoh Ontosoroh ini Pram mengangkat sosok Nyai yang saat itu dianggap sebagai wanita pribumi, yang malas dan bodoh, menjadi Nyai yang pintar, mandiri, dan pekerja keras. Sekalipun Ontosoroh menguasai perusahaan dan pertanian milik warisan almarhum suaminya, ia tidak mengubah status dirinya dari seorang Nyai menjadi Nyonya Besar. Ia tetap konsisten dengan diriya sebagai seorang Nyai, suatu pribadi yang unik gaya Pram. Dengan fasilitas mewah yang didapat dan dikuasai, Nyai tidak mengalami kejutan budaya, apalagi guncangan budaya (cultural shock). Justru tokoh ini mampu beradaptasi dengan budaya baru dengan tetap memperhatikan budaya lama. Tokoh wanita ini hadir dalam lintas budaya dengan selamat, aman, dan nyaman.

Melalui kisah Nyai, Pram menunjukkan kepada pembaca bahwa menyikapi kondisi bangsa kita perlu melakukan transformasi budaya. Ontosoroh seorang gadis desa, terpaksa menjadi "nyai" Belanda. Dengan status nyai ini ia menyesuikan diri menjadi seorang wanita pribumi yang mampu berbahasa Belanda dan berbudaya modern, tanpa harus meninggalkan etnisitas kejawaannya. Dengan demikian, Ontosoroh turut mengubah karakter perempuan Jawa yang sering "pasrah pada nasib" menjadi perempuan pekerja keras yang sukses mengelola perusahaan. Dalam novel ini Nyai juga terlihat, bagaimana dirinya tidak menolak budaya Barat, tetapi memanfaatkan budaya Barat sebagai strategi untuk melakukan eksistensi dirinya dengan belajar berbagai hal dari budaya Eropa.

\section{Simpulan}

$\begin{array}{cccc}\text { Novel Bumi } & \text { Manusia karya } & \text { Pram } \\ \text { merupakan } & \text { karya } & \text { sastra yang } & \text { dapat }\end{array}$ mmemperkaya pemahaman lintas budaya karena mengandung beberapa hal, yakni karakteristik budaya tokoh protagonis, konflik budaya antara tradisi dan modern, pribumi dan nonpribumi, budaya Barat dan Timur. Pertentangan yang tak dapat dielakkan dalam realitas itu berada dalam posisi antara pihak penjajah dan terjajah. Kondisi tersebut meningkatkan eksistensi sastra Indonesia sebagai media komunikasi lintas budaya. Tokoh protagonis dalam Bumi Manusia, Nyai Ontororoh alias Sanikem mewakili kelas bawah sebagai wanita pribumi mendapat pengaruh budaya modern dari suami Tuan Mellema dan lingkungannya. Akibat pengaruh itu Nyai dapat bersosialisasi dan beradaptasi dengan budaya modern, tanpa meninggalkan budaya tradisi. Ia menolak dipanggil dengan sebutan Nyonya Besar, suatu istilah yang pas untuk istriistri pejabat Belada era kolonial di Indonesia. Untuk era milenial seperti sekarang ini barangkali agak susah menemukan sosok seperti Ontosoroh yang konsisten dengan pribadinya. Pengarang Pram menampilkan sosok perbadi Nyai yang unik dan kontradiktif. Hal ini tidak terlepas dari latar kehidupan pribadi pengarang yang juga kontradiktif, sempat dicaci oleh lawanlawan politiknya dan dipuji karena karyakaryanya menembus dunia.

\section{Daftar Pustaka}

Bandel, Katrin. 2013. Sastra Nasionalisme Pascakolonialitas. Jakarta: Pustaka Hariara.

Darma, Budi. 1998. "Sastra Indonesia dan Forum Internasional" dalam Kongres Bahasa Indonesia VII. Jakarta: Departemen Pendidikan dan Kebudayaan.

Djokosudjatno, Apsanti. 2000. "Kosmopolitisme dan Pengetahuan Ensiklopedis Pramudya Ananta Toer" dalam Horison Tahun XXXV, No. 9, September.

Djokosudjatno, Apsanti. 2004. Membaca Katralogi Bumi Manusia Pramoedya Ananta Toer. Magelang: Indonesia Tera.

Haryoto. 2007. "Potret Impotensi Agama dalam Gadis Pantai" dalam 26 Naskah Terbaik. Jakarta: Depdiknas.

Rosidi, Ajip. 2006. "Kenangan 52 Tahun" dalam Horison No T3.2, Tahun XLI.

Samboja, Asep. 2010. Historiografi Sastra Indonesia Tahun 1960-an. Jakarta: Bukupop.

Santosa, Puji. 2011. "Multikulturalisme Sastra Indonesia Modern Memantapkan

Peran Sastra Indonesia Modern dalam Menghadapi Budaya Global,"

Makalah dalam Kongres Bahasa Indonesia 2003.Jakarta : Badan Pembinaan dan Pengembangan Bahasa Kemendikbud. 
Soedibyo. 2003. "Memori Pasionis, Kultur Amnesis dan Cerita dari Blora." Dalam 25 Naskah Terbaik.Jakarta: Depdiknas.

Toer, Pramoedya Ananta. 2001. Bumi Manusia. Jakarta: Hasta Mitra.

Toer, Pramoedya Ananta. 2009. Gadis Pantai. Jakarta: Lentera Dipantara.
Wahyudi. 2008. "Pembentukan Identitas Kedirian Nyai Ontosoroh dalam Bumi Manusia-nya Pramudya Ananta Toer" dalam 25 Naskah Terbaik. Jakarta: Departemen Pendidikan Nasional 